\title{
sciendo
}

DOI: $10.2478 /$ abcsj-2019-0018

American, British and Canadian Studies, Volume 33, December 2019

\section{The Uses of Formulaic Language in Graham Swift's England and Other Stories}

\author{
BOŻENA KUCAŁA \\ Jagiellonian University in Kraków, Poland
}

\begin{abstract}
This article argues that in his collection of short stories England and Other Stories (2014), as in most of his fiction, Graham Swift is preoccupied with the limits of language, with what remains unsaid or is poorly communicated. In this volume, the writer's focus on private, domestic and ordinary lives corresponds to his representation of the language of everyday interaction as essentially non-creative and formulaic. Swift's deliberately clichéd language reflects what, as contemporary studies of discourse reveal, is a standard mode of social interaction. For example, Roberta Corrigan et al. affirm that linguistic formulae should be considered as yet another manifestation of behavioural routines (xxiii-xxiv), while Alison Wray claims that the reliance on formulaic language "predominates in normal language processing" (Formulaic Language 101). A range of uses of formulaic language is analysed in selected stories from the collection. It is demonstrated that, typically, characters choose prefabricated language for the paradoxical purpose of establishing and maintaining a degree of contact with others while avoiding in-depth interaction.
\end{abstract}

Keywords: Graham Swift, England and Other Stories, contemporary English fiction, short story, formulaic language, cliché, inarticulacy

After the four decades of Graham Swift's novelistic career, the critical assessment of his oeuvre is now due for a realignment. From the present vantage point it appears that Waterland (1983), the book which brought him acclaim and general recognition, and arguably remains his bestknown achievement to date, was an exception rather than a representative example of his fiction. After the first two novels, ${ }^{1}$ which recounted personal traumas within the narrow confines of a domestic milieu, 
Waterland, featuring an eloquent, knowledgeable narrator ambitiously setting his family tragedies against the grand narrative of History, seemed to point a new direction in Swift's work. However, contrary to expectations, the writer returned to the relatively narrow scope of his previous fictional settings. In his 2003 monograph on Swift, David Malcolm described two of his novels, The Sweet-Shop Owner (1980) and Last Orders (1996), as "a narrow world" I and II, respectively $(24,158)$, whereas The Light of Day (2003) was analysed as "a narrow way" (187). Wish You Were Here (2011), which was released after the publication of Malcolm's monograph, could certainly be termed "a narrow world" III. Swift justifies the "localness" of his fiction by pointing out that "life is about our little corner, our little nook, our little niche, our little territory" (Craps 652).

The writer's decision to tone down his narratives stemmed, among other things, from his growing scepticism about expressiveness. In an interview with Catherine Bernard in 1997, Swift professed:

I think I want more and more to be simple. I want to do less to achieve more, which dramatically implies that you shouldn't repeat yourself. I think there was a degree of overemphasis in Waterland, and if I can be self-critical, it's possible that because it was a long time ago, Waterland contained perhaps a little too much repetition, an underscoring of things, excessive emphasis. (221)

Indeed, although regarded as a classic in modern English fiction, Waterland in retrospect appears to be "something of an anomaly within [Swift's] oeuvre" (Lea 4), which is typically preoccupied with "the smallness of ordinary lives" (Lea 3). Swift's protagonists tend to be, in the words of Stef Craps, "humble, unheroic, vulnerable elderly men who are forced by a crisis situation in their personal lives to face up to an often traumatic individual and collective past" (637-38). ${ }^{2}$ The writer's concern with the big problems of small lives is paralleled by his style, through which he wishes to, as he put it in an interview, "make ordinary simple words do extraordinary things" (Widdowson 92).

Swift's seemingly incongruous desire to achieve more through being simpler owes much to his recognition of the paradoxical eloquence of silence, inarticulacy and formulaic language. In another interview, 
given after the publication of England and Other Stories (2014), Swift claimed,

I strongly believe that there's more to people than what they say or show or, sometimes, even know. I'm drawn to inarticulacy because I think a large part of life - the life inside us - goes largely unarticulated. How many people walk around thinking: No one knows my story, no one knows what's inside me? So it's one of the functions of fiction to break the silence, say the unsaid, tell the stories that don't get told. ("Graham Swift")

What is unsaid or merely hinted at prevails over his characters' interior monologues. The Light of Day has been described as "a very quiet novel," characterised by "an intensely economical use of words," "extreme brevity and concision of the sentences," "[a] very simple and matter-of-fact style" and "a general sense of restraint and control" (Tollance 63). A similar set of features may be found in The Sweet-Shop Owner, Last Orders, Wish You Were Here, as well as England and Other Stories. Within Swift's fiction, Tomorrow (2007) represents an extreme juxtaposition of speech and silence by taking, in its entirety, the shape of a narrative delivered to a non-listening audience, after the narrator makes sure that her children are asleep and therefore unable to hear and respond to what she is about to say (which, at any rate, is probably only verbalised internally). Jonathan Derbyshire described Swift's novels as "symphonies of inarticulacy ... using the clichés, solecisms and crabbed cadences of everyday speech" (62).

This article aims to explore Swift's employment of clichéd language in his second volume of short fiction, which has attracted very little critical attention so far, perhaps owing to the deceptive mundanity of the stories. It will be argued that Swift's characters have recourse to formulaic language as an intermediate option, an alternative to both complete inarticulacy and successful communication. If no one knows what is inside them, this is because they do not wish to communicate too much, while at the same time they try to maintain the necessary level of social interaction. 
"Calculated Ordinariness"

The collection England and Other Stories is (with the exception of "Haematology"3) firmly grounded in the here and now, in the familiar everyday reality of the lives of ordinary people. United by "a calculated ordinariness" (Dennison), they lead "lives of quiet desperation" (Runcie). Michiko Kakutani detects "Larkinesque clouds of disappointment" hanging over the characters' lives, which are recounted by the writer "in a minor key," and praises Swift's ability to "distill nuanced emotional truths from the effluvia of ordinary life." “'Ordinary' and 'everyday' are not everyone's idea of a good read" - notes Rachel Seiffert in her review of the volume, but she goes on to praise Swift's characterisation and his "clear" and "careful" prose. The characters are typically middle-aged or elderly, contemplating, on the one hand, their past and present losses and disillusionments, and, on the other hand, preparing to confront yet more losses and, eventually, their own mortality. Following the implication contained in the title that the stories collectively depict a place, the social setting could be said to offer yet another glimpse of what Malcolm called Swift's "narrow world."

The protagonist of Waterland, taking the eternal cycle of water as a metaphor for the repetitiveness and cyclicality of human life, stated that "Reality's not strange, not unexpected. Reality doesn't reside in the sudden hallucination of events. Reality is uneventfulness, vacancy, flatness. Reality is that nothing happens" (34). Nevertheless, his own narrative is pinpointed by, and, accordingly, revolves around dramatic events which interrupt the flow of a mundane existence. By contrast, the stories in England and Other Stories blur the distinction between the banal and the extraordinary rather than emphasising it. This effect is achieved by the mode of narration, which alternates silence, understatement and formulaic language. In the words of Lucy Scholes, "Reduction in all its forms is something of a theme in Graham Swift's collection, both in form and content." At face value, the ostentatiously reductive use of the resources of language aims to play down, understate and suppress the harrowing aspects of life but a closer analysis suggests that this strategy is also well suited to reflect the omnipresence of loss, 
grief and tragedy in the characters' daily life, with the result that they do not seek novel language through which to convey their experiences, instead relying on well-rehearsed patterns. In other words, Swift's stories intimate the existence of correspondences between, on the one hand, the repetitiveness and mundanity of ordinary life, and, on the other hand, the predictability and restrictiveness of the language people tend to use.

Similar claims have been made in the linguistic studies of discourse. In the Introduction to Formulaic Language, Roberta Corrigan, Edith Moravcsik, Hamid Ouali, and Kathleen Wheatley contend that linguistic formulae have parallels outside language: "Frequently performed routines such as playing a favorite piano piece, starting a car, brushing one's teeth, or even walking are akin to linguistic formulae in that they, too, form unified chunks of behavior" (xxiii-xxiv). Both linguistic and non-linguistic behaviours are governed by the same law of psychology: a preference for things which have been previously experienced (Bannard and Lieven in Corrigan et al. xxii). Indeed, according to Alison Wray, formulaic language tends to be the first choice in processing language: "it is the accessing of large prefabricated chunks, and not the formulation and analysis of novel strings, that predominates in normal language processing" (Formulaic Language 101). Recent studies employ the notion of formulaic language as an umbrella term for prefabricated units of language, such as:

(oral) narratives, prayers, proverbs, social routines, non-compositional idioms, (more or less) transparent idioms, collocations, lexical bundles, sentence stems, complex word forms, frequently used sequences of words and clauses, fixed sequences, sequences with open slots which can be filled subject to varying levels of constraints, community-wide sequences and idionsynchratic [sic] sequences. (Weinert 2)

Research reveals that one quarter of standard conversational interaction is made up of formulaic utterances (Sidtis 449). Based on a very broad definition of formulaicity, other studies estimate that over half of natural spoken and written English is formulaic rather than novel (Erman and Warren in Weinert 5). 
“In All His Life He'd Never Stumbled Upon”

Although it may seem reasonable to suppose that new experiences elicit novel language, the opposite is often the case - when confronted with an unfamiliar situation, the speaker may be inclined to fall back on familiar language. As Carlos Alfredo Yorio notes, "conventionalized forms" have a stabilising role in communication, making it "more orderly" since they are "regulatory in nature." Fixed chunks of language "offer social support to deal with situations that are awkward or stressful" (qtd. in Wray, Formulaic Language 52).

In Swift's short stories, the characters' typical response to personal catastrophe and pain is emotional restraint, paralleled by verbal selfcontrol which manifests itself either in silence or clichéd language. In "First on the Scene," an elderly man struggles with his grief over the death of his wife by performing the ritual of taking solitary walks in the places where they once walked together. The comfort which this repetition offers is encapsulated in the clichéd expression he reiterates: "This is as good as it gets," which functions both as a reminder of his times with Lynne, and a way of persuading himself that he has found a solution to his loss: "He used to say it to himself nearly every time he walked with Lynne. But he said it also now. It was important. It wasn't true now, because when he'd said it to himself while walking with Lynne everything had been so much better. But it was also true now. It was true and it wasn't" (248).

The routine is violently disrupted when Terry comes across the corpse of a young woman during one of his walks in the countryside. Apart from shock, his immediate reaction is anger at having been unwittingly involved in someone else's tragedy, in a role that is minor, accidental and yet also vital, since it has fallen to him to report the death. The encounter with a stranger's death leaves him stunned and speechless, and contemplating the possibility of withdrawing quietly without having to tell his story to anyone. As he tries to describe the situation to himself, he resorts to formulaic language: he was "the first on the scene" (253); he "“[s]tumbled upon': that was another phrase. In all his life he'd never stumbled upon" (252). However, after eventually contacting the police by phone, he is again lost for words: "He hadn't a clue how to begin" (255). 
The story breaks off at this point, leaving the character hesitating between silence and conventional phrases.

\section{"He Didn’t Have to Say It, I Didn't Have to Ask"}

Laurence Tatarian observes that in Swift's works "[t]he narrative process hovers between telling and not telling" (38). Such contradictory intentions may take the form of a combination of silence and clichés, which enables some exchange of ideas while "bleaching" them semantically (see Corrigan et al. xxii). This strategy determines the conversation between a barber and his client in the short story "People Are Life." The actual utterances remain superficial yet hint at the unsaid, just as the service requested and rendered appears to be merely a pretext for oblique revelations that one would be more likely to make in front of a close friend - that neither man has. In between silences, when the barber is cutting his hair, the client confesses that his mother has just died. The barber senses that the man's reflection in the mirror reveals more than his speech, and his head hides unarticulated thoughts: "sometimes I think: Right there beneath my fingers is [someone's] skull, their brain and every thought that's in it" (24-25). The narrator decodes the full message: "What he was telling me was that he was all alone in the world" (25). His own responses, however, match the client's clipped utterances; in a string of clichés he perfunctorily offers the consolation that is apparently expected of him: “"Well it has to happen ... sooner or later"” (24), "Still, it's tough,"” "“That's not bad. Eighty-three's not a bad age,"” “"But you have friends" (25), and "People are life" (26). These and similar "readymade chunks" enable him to "verbalise instructive wisdom" or bridge pauses in the conversation (see Jaki 5). Alternatively, the narrator simply echoes his interlocutor's utterances, or utters meaningless words just to maintain contact: “'Well', I said"”; “Well', I said”" (24). Presumably, both speakers realise that their conversation does not go beyond a certain social ritual: "maybe he knew that I hadn't meant what I'd said. I'd said something everyone says, or likes to think" (26). The narrator's wellconcealed irritation at having been drawn into a quasi-confessional interaction and placed in the position of a comforter is also due to the fact 
that he is just as lonely and friendless as his client, therefore feeling all the more acutely the artificiality of the stock phrases that they both use in order to retreat from self-articulation. His own memories and reflections constitute his inner monologue but remain unverbalised, and this he regards as the proper mode of behaviour.

\section{“Ever Feel There’s Too Much Tragedy About?”}

If Swift's use of conventionalised language forms is no doubt deliberate, he also makes many of his characters self-conscious about the formulaicity of their language. Even when using unremarkable, hackneyed words and phrases, the characters stumble over them, repeat them and ponder upon them until they stand out as linguistic choices rather than mere habits of speech.

A character in "Tragedy, Tragedy" complains about the excessive use of the term in the media. His conversation with the unnamed narrator of the story has been sparked off by a recent fatal incident at work. Sitting in a canteen over a morning paper, Mick carries out an elementary, naïve analysis of the discourse of the media, objecting to the unreflective, widespread application of the notion of tragedy: “'Tragedy' .... When bad stuff happens, when people die. It's always a tragedy, it's tragic. That's what the papers say. Tragic" (95). One of Mick's objections is the supposed restriction of the concept of tragedy to politicians or media celebrities, "a Member of Parliament or someone on TV" (96). Mick's other concern is what kind of circumstances justify the evocation of tragedy. His conclusion is that tragedy has been reduced to "just a word they use in the papers about things they get into the papers" (96). The character's unskilled arguing is provoked by his recognition that Ronnie's death, which greatly upset his workmates and his family, would not qualify as tragedy for the newspapers - an ordinary worker's heart attack on a forklift would be precluded from such a denotation, or most likely would simply be ignored as not newsworthy.

Unbeknown to the interlocutors, the discussion in the canteen invokes Aristotelian definitions. Tragedy, as Aristotle specifies in The Art of Poetry, "is a representation of an action that is worth serious attention, 
complete in itself, and of some amplitude; in language enriched by a variety of artistic devices" (38-39); furthermore, the action must involve "agents who necessarily display certain distinctive qualities both of character and of thought" (39). Mick's artless grievances against the supposed misappropriation of the word "tragedy" may in fact be read as a challenge to the Aristotelian formula. The narrator, who remains for the most part quiet and unresponsive during Mick's tedious reasoning, is also preoccupied with the meaning of the word and acknowledges its superficial, conventional use: "I thought, Tragedy's about acting too. It's about stuff that happens on stage. Shakespeare and stuff. That's the thing about it. It's not real life" (99). His own objections stem from the perceived artificiality of the distinction between tragedy and comedy. Recollecting the circumstances of Ronnie's death, the narrator silently admits that although this death was not without its funny aspect, one cannot possibly say it (102). In parallel to the traditional theatre which observed literary conventions, in real life, which is a drama inevitably made up of both tragic and comic elements, people also prefer to adhere to language conventions instead of seeking to convey the complexity and ambiguity of their experience.

\section{"But He Wasn't Really Listening"}

Insofar as formulaic language facilitates communication at a superficial level, it impedes authentic, creative expression and interaction. But in certain circumstances the former may be the preferred option. As Michael R. Perkins notes, "the main reason for the prevalence of formulaicity in the adult language system appears to be the simple processing principle of economy and effort" (qtd. in Wray, Formulaic Language 15-16). Formulaic phrases reduce both the speaker's effort to convey a message and the listener's effort to decode it (Wray, Formulaic Language 93), especially when the speaker has no intention of engaging in depth with his or her listener but wants to achieve only "a low-level, background reaction," without instigating further interaction (Wray, Formulaic Language 95). 
In Swift's short story, the word "tragedy," in its trivialised sense, has its use in social interactions as a convenient, ready-made alternative to creative, subjective responses. If, as Mick notes, "tragedy" is a word the newspapers use "because they can't think what else to say" (96), the same holds true of daily interactions. The narrator recollects that this is also the word the manager repeatedly used while talking to Ronnie's widow: "He said, 'It's tragic, Mrs Meadows. Tragic... tragic.' He said it several times. He looked like he didn't know what else to say, and Ronnie's wife looked like she wasn't listening" (97).

Without sharing his observations with Mick, whom he treats with a degree of impatience and condescension, the narrator intuitively recognises that examining the actual meaning of "tragedy" is beside the point, since the term simply offers a convenient way of coping with a socially distressing situation, or, as linguists would prefer, belongs to "a huge store of standard ways of referring to standard situations and phenomena in a speech community" (Erman 326). Talking about death certainly calls for what Andrew Pawley has named "subject matter codes" (qtd. in Wray, Formulaic Language 72-73); culturally agreed patterns specify what may be said in a given context, as well as how. "Conventionalized forms ... organize reactions and facilitate choices, thus reducing the complexity of communicative exchanges" (Yorio qtd. in Wray, Formulaic Language 52). Abandoning formulaicity could release new meaning (Wray, "Identifying Formulaic Language" 48), but clearly neither the manager nor Ronnie's widow is interested in facing the challenge of novelty.

Numerous episodes in Swift's other stories further illustrate the role of formulaic language as a welcome deterrent to in-depth interaction. Whereas the narrator of "Tragedy, Tragedy" witnesses other people's reactions to and ways of coping with their workmate's death, Eliot, the protagonist in "I Live Alone," is directly involved in an exchange of distressing news. In the course of the story, he assumes different roles in turn: first as a recipient of bad news, then as the one who controls socially awkward circumstances. Both his encounters with life-changing situations, or "tragedies" - to borrow the over-used term - take place in professional contexts. The first part of the story recounts Eliot's visit to a 
doctor who informs him that he suffers from an incurable illness. The realisation of the finality of his life causes Eliot to drift mentally to memories of his late wife, his present loneliness, and his own imminent demise. He watches the doctor speaking, but no longer listens to what is being said. Both doctor and patient, self-consciously, resort to a few formulaic phrases:

Grant continued to speak, but he didn't listen or couldn't focus. It was enough - surely enough since it was everything - to have to take in the main thing. He'd already asked the question that he'd never thought he'd hear himself ask, the question people only asked in films. And Grant had answered, though through a sort of fog. Had he said six months or eighteen, or that it could be anywhere between the two? Grant was now speaking of what might be done to 'maximise his quality of life' (had he heard that phrase?). But he wasn't really listening. (217)

Eliot knows such situations from the other side when he, as a lawyer, is obliged to convey upsetting information to his clients, without straying from his professional mode of behaviour. The protagonist's other appointment on that day is with a woman seeking his advice in a divorce case, a woman clearly dismayed at the break-up of her marriage. Eliot immediately recognises a symmetry between those two episodes, and a reversal of roles - this time he is the one who relies on habitual gestures and well-rehearsed language. But, as he has earlier reflected, "what could you do except carry on?" (217).

\section{"She'd Have to Live Through It Every Year"}

Not only speech communities, but also individuals develop their own formulae. Experiments prove that if asked to retell a story or recount a situation several times, people tend to move from spontaneity and production to repetition and reproduction (Wray, Formulaic Language 84$85)$.

The process of getting into a habit of retelling is shown in Swift's short story "Was She the Only One?". The narrative depicts a woman's brief first marriage to a man who is shell-shocked and eventually killed during the Great War. Memories of their relationship, his odd behaviour 
triggered by the experience of the trenches and her reaction to it are engraved on her mind, but she refuses to share them with her second husband, her daughters and granddaughters. She has deliberately reduced her story to a few basic facts and adjusted it to the common pattern of war-time family narratives. Although her experience once seemed to Lily so unique that, when married to Albert, she asked herself if she was the only one, over the years she has arrived at a simplified, socially recognisable narrative pattern: "she'd been married before, then widowed. She wasn't the only one. It had all taken less than a year. His name was Albert" (176).

\section{"It Had Become His Watchword"}

Formulaic expressions are characterised by "stereotyped form, conventionalized meaning, and familiarity." When they contain "precisely specified words in a certain word order spoken on a set intonation contour," they may take on the role of social signals. For example, the expression "I met someone" communicates more than neutral information; it has "innuendos of excitement and romance, which extend over and above the words themselves" (Sidtis 447).

The protagonist of "I Live Alone" habitually uses the titular sentence to identify himself. ${ }^{4}$ Ten years after the death of his wife, he is still haunted by memories of their life together and feels Anne's presence in his daily activities. His bereavement appears to be a defining feature of his present existence. The sentence certainly communicates more than the sum of its parts - although Eliot does not normally share further details about his private life, he counts on this utterance to arouse a set of connotations in the people he interacts with, but chooses not to specify his exact meaning:

It had become his watchword. He said it to clients, particularly clients he was guiding through the troublesome process of divorce, and he could say it with a judicious ironical tone, even a crinkly smile. So they could never tell what he really meant. An expression of sad fact? Or of proud resolution? An explanation, or a recommendation? (218) 
Thus, the protagonist achieves what many of Swift's characters do: a tentative balance between telling and not telling, between silence and successful communication.

\section{"It Was Others Speaking Out"}

In the stories cited above, dialogue by means of prefabricated language is a matter of mutual, tacit consent, as well as of mutual benefit. Yet the effort that is saved in processing language may come at the price of distorting or manipulating meaning.

Wray points out that formulaic language may serve, and indeed has been known to serve, as an instrument of social and political control. She invokes George Orwell's insight that the manipulation of thought begins with the manipulation of the language in which ideas can be expressed (Wray, "Identifying Formulaic Language" 44). In his dystopian vision of a totalitarian state in Nineteen Eighty-Four (1949), Orwell stressed the crucial role of Newspeak as a party-invented, simplified language, aimed at making the citizens incapable of independent thought. In his essay "Politics and the English Language" (1946), Orwell warned against the effects of using formulaic language: "modern writing at its worst ... does not consist in picking out words for the sake of their meaning .... It consists in gumming together long strips of words which have already been set in order by someone else" (344-45). The effect is that

you are not obliged to go to all this trouble [of thinking about your writing]. You can shirk it by simply throwing your mind open and letting the ready-made phrases come crowding in. They will construct your sentences for you - even think your thoughts for you, to a certain extent and at need they will perform the important service of partially concealing your meaning even from yourself. (346)

Swift's short story "Yorkshire" exposes the risks of borrowing fixed elements of communal speech, of using other people's lexicons. The story recounts a situation in which breaking the habit of silence, secrecy and taboo results in falling back on a recognisable pattern of speech, which effectively obfuscates the truth. The story captures Daisy Baker on a night when for the first time in her fifty-year marriage she is separated 
from her husband, who is about to be interrogated by the police in the morning. ${ }^{5}$ Their middle-aged daughter Addy has just accused her father of abusing her sexually in her childhood. The darkness of the night corresponds to the dimness of Daisy's memories; shocked by Addy's allegations, Daisy tries but cannot recollect any reliable evidence that could substantiate them. Equally upsetting is the fact that Addy's disclosure has broken the family's practice of tabooing trauma ("Years went by and people never talked" [119]). Both Daisy's grandfather and husband kept silent about their experiences during the first and second world wars, respectively, so whatever was known about their soldierly lives remained a family secret.

But the protagonist's resentment of her daughter's action stems not only from her own habit of secrecy, but also her mistrust of Addy's mode of speaking. The prefabricated language in which her daughter's allegations are formulated makes Daisy question their reliability. Addy's talk of suppression reminds her mother of the familiar language in which such stories are nowadays recounted and makes her suspect that Addy has appropriated chunks of language to concoct a false narrative. The fact that the narrative is built around stereotyped units of language - singled out in the text by means of inverted commas - arouses her suspicion that her daughter is not talking about authentic experiences:

She, Adele Hughes, born Baker, hadn't talked for over forty years, but she was talking now. She's kept it to herself, she's 'struggled', but now she had to 'speak out'.... And she wouldn't be the only one to speak out, would she, not by a long way? The world knew that by now. It was others speaking out that had given her the courage.

Courage?

She said she'd been 'traumatised'. All her life she'd struggled. But it had to stop now. She had to have her 'release' (119).

Confronted, on the one hand, by her husband's silence and, on the other, by her daughter's clichéd language, the protagonist is unable to ascertain the truth. 
Conclusions

Within the entire volume of Swift's short stories, "Yorkshire" and "Tragedy, Tragedy" present rare instances of characters resenting formulaic language as an impediment to genuine communication. In other situations, fixed expressions are the preferred mode of interaction. Characters are unwilling to express the depth of their pain, trauma or loss.

If a tragedy happens to them, it becomes incorporated into the fabric of daily life, including their ritualised everyday language. In one of the most memorable stories in the volume, "Fusilli," the pasta section in a local supermarket becomes a place of remembrance, since it was there that the protagonist received what was to be the last phone call from his soldier son before his death in Afghanistan. A humble packet of fusilli, which his son recommended to him then, is converted to a private symbol of the father's grief, and the recollection of the banal words they exchanged on that occasion becomes his ritual of mourning.

Wray's claim that, despite the diversity of the uses they can be put to, formulaic sequences usually are linguistic solutions to non-linguistic problems (Formulaic Language 101) appears especially pertinent in the reading of Swift's stories. As the writer said in an interview, "What really matters is what lies beneath and beyond the words" ("Graham Swift"). His characters either do not have any (Mick in "Tragedy, Tragedy," Daisy in "Yorkshire") or choose not to use (Eliot in "I Live Alone") their creative linguistic capacity. The formulaic patterns they resort to perform several functions: clichéd expressions facilitate quick language processing while reducing the effort of verbalising one's experience; they establish a code of signals between the speaker and the listener by eliciting predictable responses and setting limits to communicative exchanges; they also enable characters to subsume their individual lives into communal frameworks. Their language is a part of their daily social ritual, in which only the superficial aspects of the characters' experience become articulated. An analysis of Swift's stories indeed suggests that the clichéd language his characters employ is a reflection of and an equivalent to the human inability to communicate fully with others, which is a staple concern in the majority of his fiction. It may be suggested that, from the reader's 
perspective, the contrast between the calamities the characters face and the hackneyed language they use to talk about them exposes rather than conceals the depth of their "buried life" beneath the surface of ordinariness.

\section{Notes:}

${ }^{1}$ The Sweet-Shop Owner (1980) and Shuttlecock (1981).

${ }^{2}$ There are exceptions, however: Tomorrow (2007) and the most recent novel, Mothering Sunday: A Romance (2016) have female protagonists.

${ }^{3}$ The story is a letter by the seventeenth-century physician William Harvey.

${ }^{4}$ Signalling a speaker's identity as an individual or a member of a group is, according to Wray, one of the major roles of formulaic sequences (Formulaic Language 93).

${ }^{5}$ Her situation resembles that of Paula in Tomorrow. In the novel, the protagonist also spends a sleepless night, dreading her children's reaction to the disclosure that she and her husband are going to make the next day.

\section{Works Cited}

Aristotle. "The Art of Poetry." Classical Literary Criticism. Trans. T.S. Dorsch. London: Penguin, 1988. 31-75.

Bernard, Catherine. "An Interview with Graham Swift." Contemporary Literature 38.2 (1997): 217-31.

Corrigan, Roberta et al. "Introduction: Approaches to the Study of Formulae." Formulaic Language. Vol. 1. Distribution and Historical Change. Ed. Roberta Corrigan et al. Amsterdam: John Benjamins, 2009. xi-xxiv.

Craps, Stef. "An Interview with Graham Swift." Contemporary Literature 50.4 (2009): 636-61.

Dennison, Matthew. "You'll Never Look at Dried Pasta in the Same Way Again: A Review of England and Other Stories, by Graham Swift." The Spectator 12 July 2014. Web. 5 Jan. 2019.

Derbyshire, Jonathan. "Tongue Tied. Wish You Were Here, Graham Swift." New Statesman 23 June 2011. Web. 20 Feb. 2018.

Erman, Britt. "Formulaic Language from a Learner Perspective." Formulaic Language. Vol. 2. Acquisition, Loss, Psychological Reality, and Functional Explanations. Ed. Roberta Corrigan et al. Amsterdam: John Benjamins, 2009. 323-46.

"Graham Swift." Foyles. [n.a.] [n.d.]. Web. 5 Jan. 2019.

Jaki, Sylvia. Phraseological Substitutions in Newspaper Headlines: "More Than Meats the Eye." Amsterdam: John Benjamins, 2014. 
Kakutani, Michiko. "Review: Graham Swift's England and Other Stories: A Darkness across Time and Fates." The New York Times 22 June 2015. Web. 5 Jan. 2019.

Lea, Daniel. Graham Swift. Manchester: Manchester UP, 2005.

Malcolm, David. Understanding Graham Swift. Columbia: U of South Carolina P, 2003.

Orwell, George. "Politics and the English Language." Collected Essays. London: Mercury, 1961. 337-51.

Runcie, James. "England and Other Stories by Graham Swift." The Independent 3 July 2014. Web. 5 Jan. 2019.

Scholes, Lucie. "England and Other Stories Review - Graham Swift's Affectionate Chronicle of Everyday Lives." The Guardian 3 Aug. 2014. Web. 5 Jan. 2019.

Seiffert, Rachel. "England and Other Stories, by Graham Swift." The Financial Times 18 July 2014. Web. 5 Jan. 2019.

Sidtis, Diana Van Lancker. "Formulaic and Novel Language in a 'Dual Process' Model of Language Competence. Evidence from Surveys, Speech Samples, and Schemata." Formulaic Language. Vol. 2. Acquisition, Loss, Psychological Reality, and Functional Explanations. Ed. Roberta Corrigan et al. Amsterdam: John Benjamins, 2009. 445-70.

Swift, Graham. England and Other Stories. London: Simon, 2014.

---. Waterland. 1983. London: Picador, 1984.

Tatarian, Laurence. "Graham Swift's Vocal Silences." Voices and Silence in the Contemporary Novel in English. Ed. Vanessa Guignery. Newcastle upon Tyne: Cambridge Scholars, 2009. 38-54.

Tollance, Pascale. "'You Cross a Line': Reticence and Excess in Graham Swift's The Light of Day." Voices and Silence in the Contemporary Novel in English. Ed. Vanessa Guignery. Newcastle upon Tyne: Cambridge Scholars, 2009. 63-73.

Weinert, Regina. "Formulaicity and Usage-Based Language: Linguistic, Psycholinguistic and Acquisitional Manifestations." Perspectives on Formulaic Language: Acquisition and Communication. Ed. David Wood. London: Continuum, 2010. 1-20.

Widdowson, Peter. Graham Swift. Tavistock: Liverpool UP, 2006.

Wray, Alison. Formulaic Language and the Lexicon. Cambridge: Cambridge UP, 2002.

---. "Identifying Formulaic Language. Persistent Challenges and New Opportunities." Formulaic Language. Vol. 1. Distribution and Historical Change. Ed. Roberta Corrigan et al. Amsterdam: John Benjamins, 2009. 2751 . 